\title{
Students' Views on Language Skills in Foreign Language Teaching
}

\author{
Yasemin Darancik $^{1}$ \\ ${ }^{1}$ Department of German Languange Education, Faculty of Education, Çukurova University, Adana, Turkey \\ Correspondence: Yasemin Darancık, Department of German Languange Education, Faculty of Education, \\ Çukurova University, Adana, Turkey. Tel: 90-322-338-6084. E-mail: ydarancik@cu.edu.tr
}

Received: March 4, 2018

doi:10.5539/ies.v11n7p166
Accepted: April 6, $2018 \quad$ Online Published: June 28, 2018

URL: https://doi.org/10.5539/ies.v11n7p166

\begin{abstract}
The four basic language skills, listening, reading, speaking and writing are indispensable parts of a language teaching. For successful and effective education and training in foreign language courses, these four basic language skills need to be developed and reinforced in accordance with the level and needs of the learners. The aim of the research is to reveal how the students who are learning foreign languages approach the four basic language skills in general terms, their opinions about the feelings and thoughts, and thus identify important problems within this subject. The problem is not to determine the position of four core skills in foreign language teaching, or to question its definition, but the problem is to show how the students approach and master these four basic skills. This research is a qualitative study and the data that is the basis of the research has been prepared with the help of a questionnaire to determine the opinions of the university students studying foreign language teaching about the four basic language skills. The results of the research have shown that the skills that students most want to develop, pay attention to and feel lacking are speaking skills. Students will be more successful and willing in foreign language lessons when they hear and understand it correctly and they can speak it correctly and effectively. This study reveals how important these skills are for verbal communication and how much it is necessary to acquire them with different approaches and methods in foreign language lessons.
\end{abstract}

Keywords: foreign language teaching, four basic language skills, listening comprehension skills, reading skills, speaking skills, writing skills

\section{Introduction}

There are four basic language skills, listening, reading, speaking and writing in foreign language education and training (Bağçeci \& Yaşar, 2007, p. 16; Barın, 1997) and they are indispensable parts of a language teaching. In language teaching these are divided into two; the ability to understand and read, and the ability to speak which are also regarded as speech and writing. On the other hand, the other indispensable elements in foreign language teaching are grammar and vocabulary (Balc1, 2015). For successful and effective education and training in foreign language courses, these four basic language skills need to be developed and reinforced in accordance with the level and needs of the learners. Taking into consideration the stages in which a child learns his mother tongue, it has been adopted to teach basic language skills in that sense in a foreign language course. When looked at textbooks in education, it is seen that there is often listening-comprehension, after that reading comes followed by talking and finally writing. In many national and international literatures, it is possible to find articles about these skills in terms of their significance and purpose, thus this study will focus only on the aims and specific features that are intended to clarify the results of the student opinions in the research. The purpose of this study is not to question and describe the definition of the four basic skills in detail, its contribution to foreign language education; because this type of work has only been done in the direction of the opinions of teachers and linguists by focusing on a certain skill (Deneme \& Demirel, 2012). For this reason, the aim of this research is to reveal how the students who are learning foreign languages are approaching the four basic language skills in general terms, their opinions on emotions and thoughts by identifying important issues within this framework. The problem is not to determine the position of four core skills in foreign language teaching, or to question its definition, but to show how the students approach the problem and master these four basic skills.

The purpose of listening-comprehension teaching is not a skill which can be defined as the ability to listen, but rather an effective stage because it can perceive the transmission from the speaker exactly and correctly. When it is spoken at normal speed, even if all the discourse of the speaker is not understood, it is expected to perceive what it means. For this reason, students are asked to recognize the changes in the meaning of the aim, the emphasis and the 
tonalities (Barın, 2002). Most language experts emphasize that speaking skills and listening skills are intertwined. (Becker-Mrotzek, 2008). Listening is more difficult than reading because you can have a chance to read the text a few more times; but the person who does not understand what you are saying has no chance of listening again.

Genç (2000, p. 101) has expressed his views on speaking ability by thinking together with his speech and understanding ability as follows.

"The ability to speak and understand a language is the ability of the student to master certain situations in possible speaking situations and react appropriately with the perception of the cultures of the foreign language he learns as well as his own cultures and his effort to understand. It is the ability to communicate with a communicative approach, a foreign language teaching method, and in an appropriate environment to meet the need for a language communication. This ability can only be formed with self and foreign culture, society, etc. and change of perspective. Communicative competence, with its linguistic competence, achieves language acquisition."

With the act of speaking, the student acquires the ability to transfer his own feelings, thoughts or knowledge to others, and on the other hand he has the opportunity to learn the feelings, thoughts and ideas of others and thus he can understand, evaluate and interpret what is happening in the world better by being equipped with the necessary knowledge and skills.

When it is looked at the examinations made about reading skills; Şahin (2010) points out that reading skills have a positive effect on other skills, namely listening, speaking and writing skills. Günay (2007) examines reading aims under two headings; information and pleasure. Reading for information purposes indicates reading in the direction of a specific target, the person reads for his / her profession or for thriving in his/her field.

İşeri (1998) also points out the aims of reading as information, enlightenment and enjoyment.

Balc1 (2000, p. 528) summarizes the importance of writing, the last skill, as follows: Writing is an important communicative tool for the development of one's identity by contributing to the development of other language skills. This skill has a feature as being an effective producer. One has to learn and develop this skill most in lessons, not alone.

Writing skills can be used to control the learning process, to determine the levels of the learners, to consolidate the teachings or words, to see the language mistakes, to teach the punctuation marks, to learn the other skills, to improve the language skills of the student by helping them transform their skills into performance. (Çakır, 2010, pp. 167-168)

In the light of these definitions, it is seen that all the skills are important and inseparable.

Here, of course, the teachers also need to have the necessary knowledge and competence in language skills. However, it is a fact that foreign language teachers do not use all the skills in this context, they work in the direction of their own mastery, and that the foreign language teaching is processed with the grammatical emphasis. "In conclusion, from a methodological point of view, the traditional method, namely, knowing the rules of language teaching, has continued to maintain its existence together with the mistakes and deficiencies in the foreign language system for training foreign language teachers." (Işık, 2008, p. 21) Many teachers are unaware of the importance of understanding and expressing the different activities and methods of language skills in reaching the lessons' targeted achievements in their lessons. In this context, a lot of studies on language skills have been done and tried to reveal the importance of language skills for foreign language teaching. In addition to this, the opinions on four basic skills have been presented in both national and international literature. These studies have often been conducted with teachers' views or with the influence and application of a particular skill (Kavanagh \& Drenan, 2008). This type of research has usually dealt with the success of certain skills, the context in which they are treated, the attitudes and achievements of students towards the course (Drese, 2007; Aktaş, 2004; Genç, 1997; Y1ldiz, 2015).

\section{Method}

\subsection{Research Model}

This research is a qualitative study and the data that is the basis of the research has been prepared with the help of a questionnaire to determine the opinions of the students studying foreign language teaching about the four basic language skills. The survey items have been selected from a pool of questions created as a result of the literature review of the field. In the questionnaire, all answers have been constructed in the same way and the answers have been given as four options: speaking, writing, listening-comprehension and reading. These options have been aimed at four basic language skills, and at the same time they have been asked to indicate why they prefer it, that is, 
to write their opinion on their answers.

\subsection{Working Group}

The study group of this research is composed of all the students who are studying both in preparation and in the language of the Department of Education of the Department of Education of Çukurova University. Information on the classes and genders of the 193 learners participating in the survey are summarized in table 1.

Table 1. Overall distribution of preparatory and undergraduate students by class and gender

\begin{tabular}{lll}
\hline Variables & & $\mathrm{f}$ \\
\hline Classes & Preparatory class & 44 \\
& $1 . \quad$ Class & 26 \\
& $2 . \quad$ Class & 52 \\
& $3 . \quad$ Class & 41 \\
Gender & $4 . \quad$ Class & 30 \\
& Female & 152 \\
& Male & 41 \\
\hline
\end{tabular}

The majority of the students who have been interviewed according to Table 1 are female participants. Another issue that needs to be mentioned at the same time is that all of the students have learned English as the first foreign language. In short, all pre-license students have foreign language experience and foreign language awareness is available. For this reason, it has been deemed appropriate to take the preparatory class to this investigation.

\subsection{Collection and Analysis of Data}

Careful attention has been paid to avoid being multi-dimensioned in order to ensure that questions are as clear as possible so that they can be easily understood and explained without creating unnecessary burden on the individual. The answers of the questions are composed of 4 chapters including speech, writing, listening-meaning and reading, and the reasons for their preference are also asked. In this study, students' thoughts have been directly addressed. Causes have been shown as an italicized citation at some point in the study and all the student views have been tried to be presented. In this sense, both those who expressed a different opinion and the ones who have the same opinions supported by the general have been determined and reflected in all dimensions. The opinions of the prepared questionnaires have been changed in line with the opinions and recommendations given by the experts. The questionnaires have been held in the spring semester of 2017-2018 in the Department of Education of German Language Education at Çukurova University. The data have been collected through personal information form and questions that have been created in parallel with the research purpose. In the evaluation of the data, "content analysis" technique has been used. This technique aims to find out how often written and spoken words are repeated (Krippendorff, 2004; Neuendorf, 2002; Tavşancıl \& Aslan, 2001; Yıldırım \& Şimşek, 2005). Before the survey is applied, the students have been asked to fill out the questionnaire with their true thoughts which are very important for this research.

\section{Findings}

Below are the 17 questions that have been created for the purpose of the research and the findings of the responses to the questions.

1) Which is the hardest learned skill for you and why?

According to the students' opinions according to the chart below, the most difficult learned skill is speaking. 


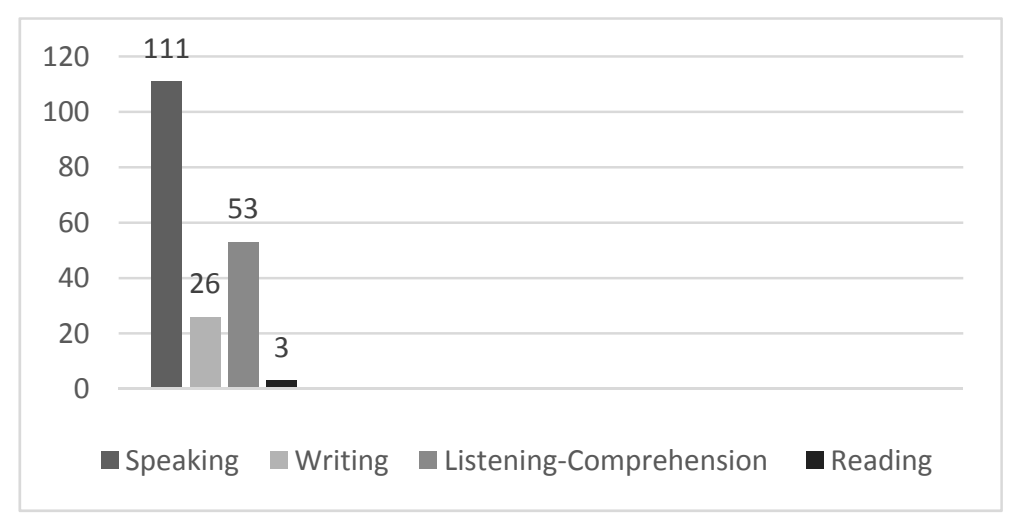

Figure 1. The hardest learned skill

Participants in the German Language Teaching Department have stated that the most difficult lesson to be learned is speaking. After speaking, listening-comprehension comes, then writing, and finally reading. In addition, the grammar and vocabulary knowledge should be very good for writing although one can make mistakes while talking and he can be still understood, and it is said that listening-comprehension skill is more difficult than others because one cannot be understood because if he is talking fast with unfamiliar voices which creates a barrier for learning. The most important reason why speaking skill is the hardest learned skill is that the foreign language is not effectively spoken and there are lack of real environments for practice, and as a suggestion, they offer more speaking courses should be done effectively. At the same time, the students have stated a wide range of vocabulary, adequate grammar and the ability to improve listening comprehension are necessary for speaking. Another factor that disturbs the students is that they are corrected immediately during the conversation which destroys their wish to speak. On the other hand, some students have claimed that the lack of self-confidence and courage, fear of making mistakes, the fear of being corrected in a face-to-face manner hinders the wish of speaking. In addition, a reason stated by a student is exactly the same as follows: Speaking skill is not emphasized enough in Turkey. Everyone has learned English since primary school, but nobody can speak. They build everything on grammar and expect us to learn. However, our language sense does not develop unless we speak.

2) Which is the easiest skill to be learned and why?

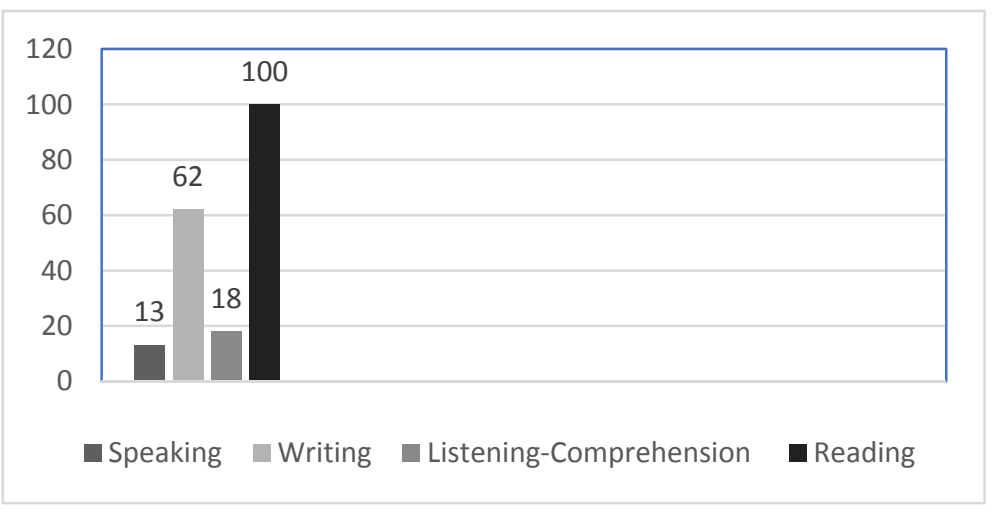

Figure 2. The easiest learned skill

In this question, the reading skill has been found to be the easiest learned skill compared to others. Even if the students do not understand the meaning of the words after learning the pronunciation of the words, they stated that the reading can be done very easily over time. A student expressed the following; reading is done in almost all lessons, and so it becomes easier and more enjoyable. Writing skill is seen as the second easiest skill and it has been claimed that writing is easier because it is possible to use a dictionary and also the writing ability is directly related to the imagination. In addition, writing and reading are easier to be learned when compared to the other skills because of constant writing and reading by correcting one's own mistakes by himself. They have stated that these two skills are easier for the students as there are more assignments for writing skills are given and reading 
skills have also been achieved in this respect.

3) Which skill is your favorite?

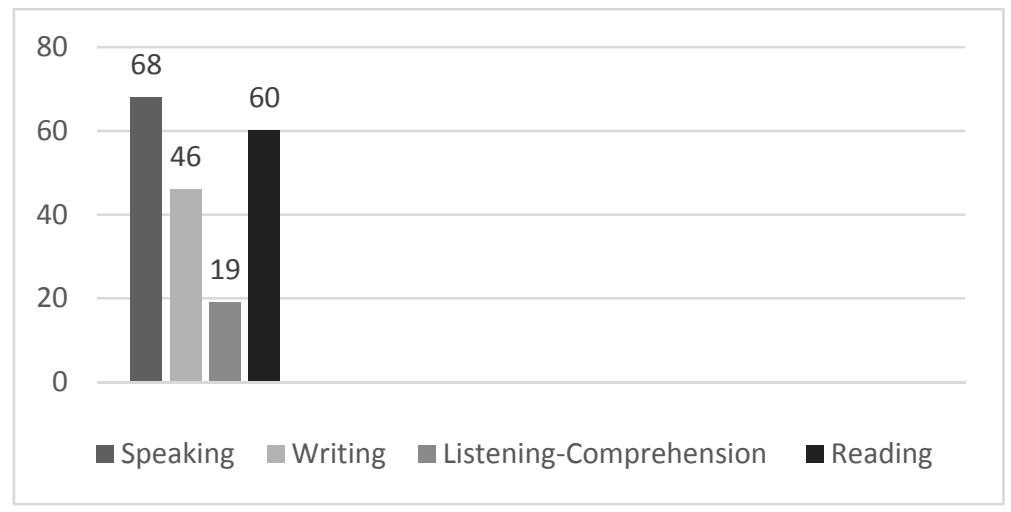

Figure 3. Most enjoyable skill

Although speaking is the most difficult skill for students to learn, it is also found the most enjoyable one. Then, it comes reading, writing and listening. Although writing is the second easiest skill to be learned, only 46 of the students here stated that they enjoyed this skill. As the listening-comprehension skill is a difficult one, the students have shown that they have not enjoyed this skill as shown in the graphic.

4) Which is the most effective skill for you and why?

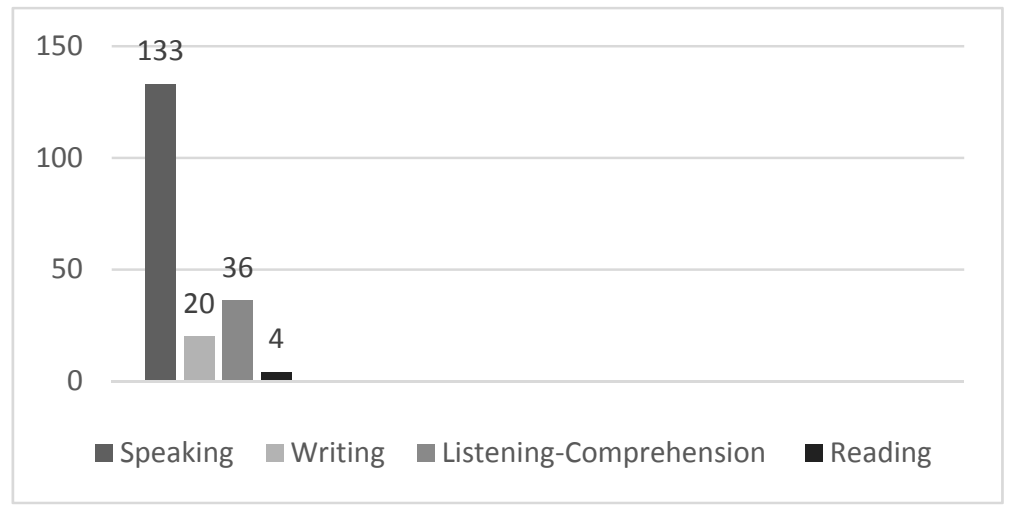

Figure 4. The most effective skill

In this question, the wishes of the students have come to the forefront. Since the students are very willing to speak a foreign, they see this skill as a most effective skill. Some of the students have explained that a person can can communicate well if he can speak the language fluently and correctly; because when the speech is good, listening and understanding, writing and reading are developing spontaneously. The more the language is spoken, the more permanent and effective it becomes. They have also talked about language sentiment, showing that there is a certain level of language awareness as future prospective teachers and that they have knowledge of foreign language teaching. I think speaking is the most important skill to be developed; because we can use the target language effectively only by speaking it.

However, in the questionnaire, a student has written a reason which disrupts the effect of speaking skill by seeing listening and comprehension skill as the most effective one; listening and understanding are very important when talking with a stranger, and communication will be better after understanding the other.

A student who finds the writing skill as the most effective has told that one can learn the language by writing more permanent. As a result, you can tell what you have in your mind and you can make many repetitions only by writing.

5) Do you need to add another skill? If yes, which skill? 
In this question there is no particular answer, it is only aimed at learning about students' thoughts, the students have a general idea that there is no need for another skill but some of them have told that there is a need to learn the culture of the target language more detailed. Morever, they have stated that extra vocabulary study and grammar can be added.

6) Priority target for me. Why?

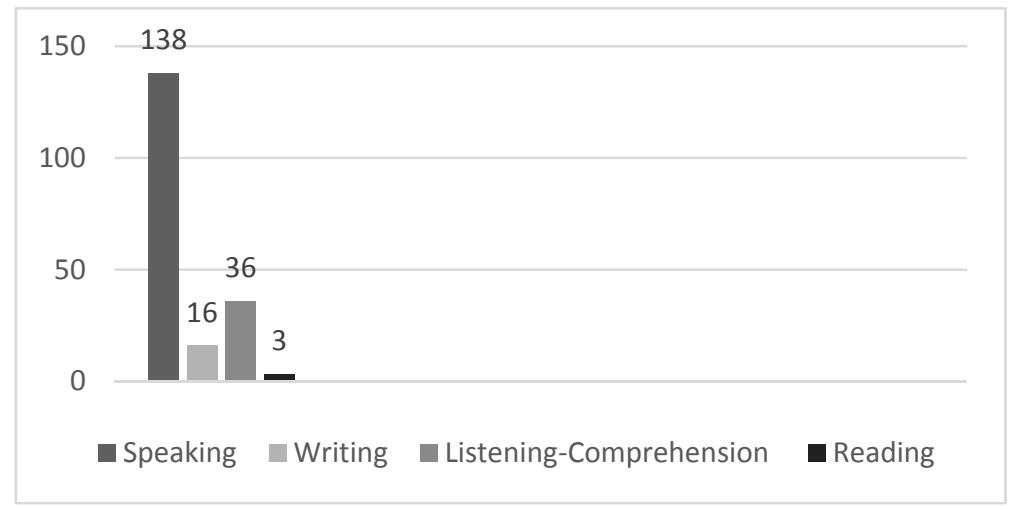

Figure 5. Priority target of the students

Most of the students have stated many times that they see themselves as inadequate in speaking as they do not have enough opportunities for talking. For this reason, their primary objective is to be able to speak the target language. Some of the reasons for their priority target are as follows:

a. Unless my speaking skill improves, I cannot reach my goal.

b. I want to apply what I have learned.

c. It's quite important for me to be able to communicate with people everywhere I go.

d. I am a teacher candidate; I need to speak to communicate with the student.

e. $\quad$ For my job applications I will be evaluated with my speaking skill first, I do not want to be the last.

f. Because for me the ability to speak a language is the most pleasant and permanent part of knowing it. It does not make much sense to know a language without speaking it.

Listening-understanding has also been shown as the second target. At this point the students have explained that understanding what they hear will also improve their speaking, writing and reading skills and thus they can be more successful. They have seen the listening-comprehension as the basics of learning a language. They have said that they can reach their goal without understanding the other; but one can read, speak and write in the course of time.

7) and 8). I see myself as adequate and inadequate for which skills.

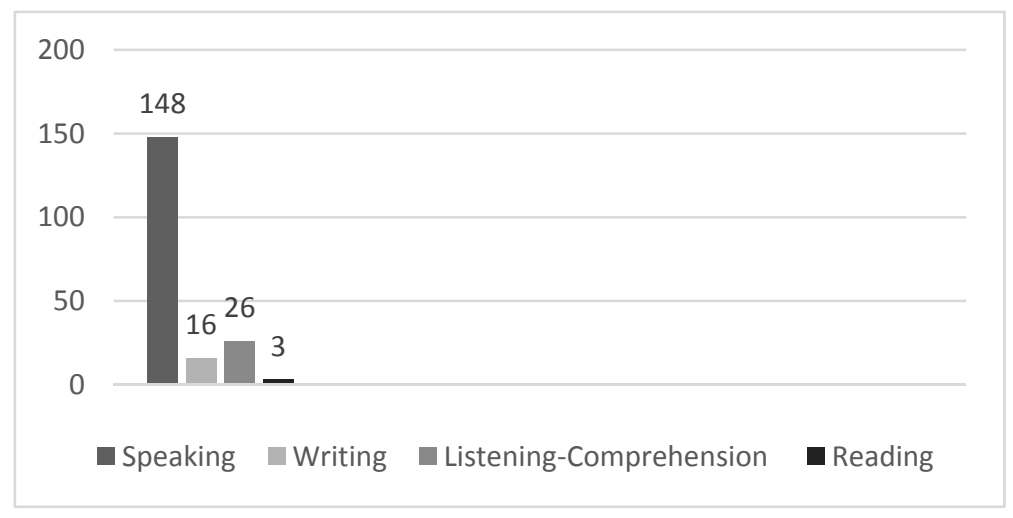

Figure 6. Adequate and inadequate skills 
The inclusion of the questions 7 and 8 in this section is considered appropriate for a clearer view of the answers. Looking at the answers given by students to this question and previous ones, the consistency of the answers of the students is striking. Students see themselves adequate to read and write, on the contrary, they see themselves as inadequate for the skills that they find difficult. Speaking skill is the skill they are most interested in, but they see themselves as inadequate for this skill.

9) Which skill do you want to develop yourself most?

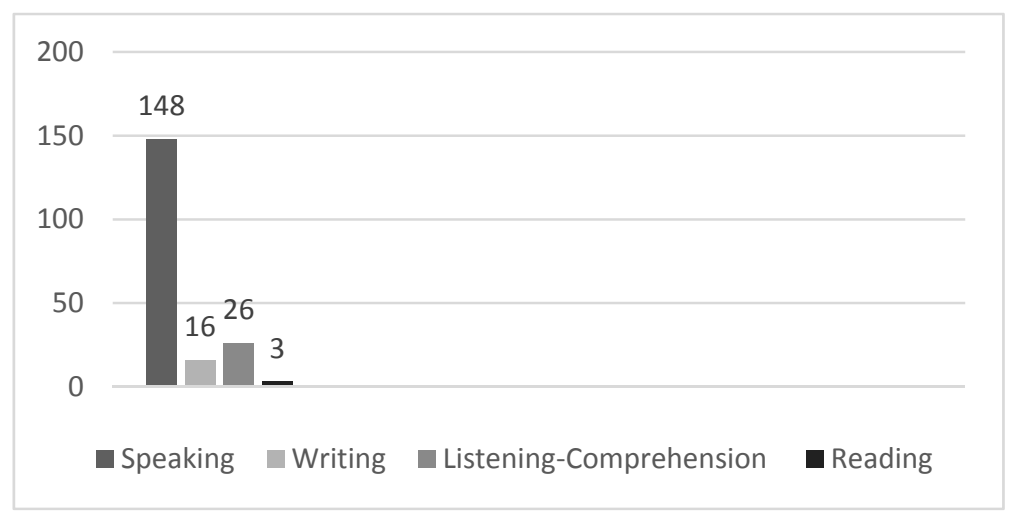

Figure 7. The desired skill

When the previous graph is examined, it can be immediately noticed that they want to improve themselves most in their speaking skills. For this question, some students says, that they want to improve themselves for their listening comprehension skills although the reason for that have not been asked. As a matter of fact, many linguists emphasize that these two skills are intertwined.

10) and 11). Which skills are the most significant and insignificant compared to others, why?

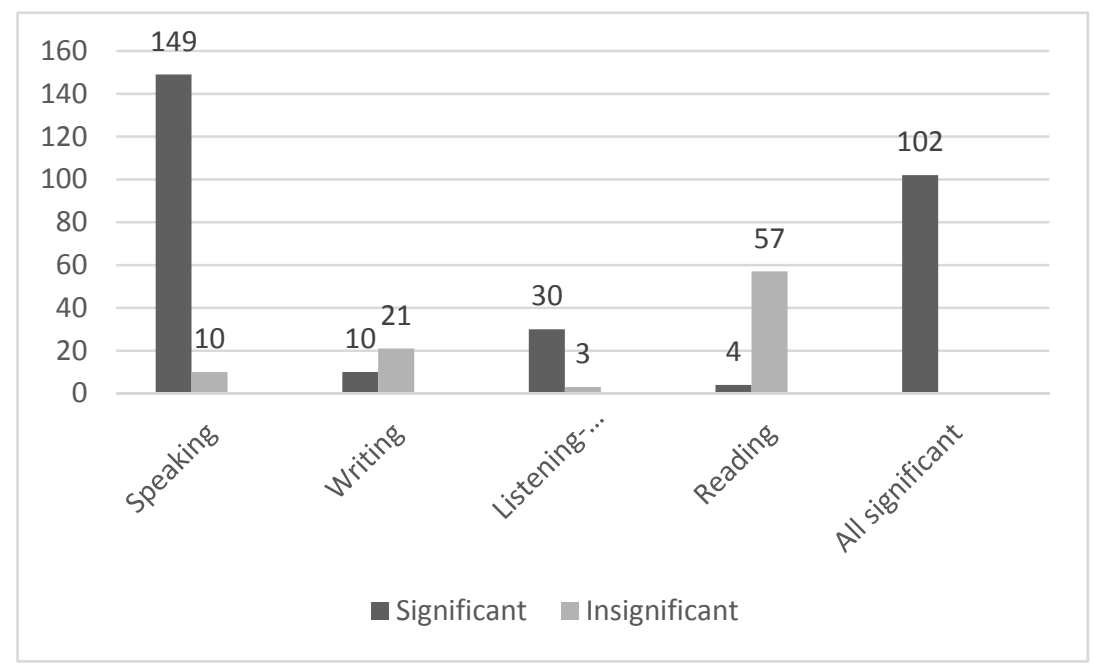

Figure 8. Significant and insignificant skill

The previous preferences of the students can also be seen here and it is thought that it would be more appropriate to have two problems in a single graph in order to be seen more clearly. The most important skill is speaking and it is followed by listening comprehension skills. Although the 11th question which has been created to find out which skill is important has no option 'none', the students have stated that all the skills are important equally and they complement each other. Those who say that reading skills are unimportant have already argued that one can do well reading if he is good at with the other three skills and thus they should focus on those three skills.

Speaking is important because; 
- $\quad$ people understand each other by speaking and it is very important for a student to be good at speaking in order to express himself.

- $\quad$ one who cannot speak well cannot learn that language.

- $\quad$ it is important to be able to speak a language first. Other skills can be improved later, but the speaking skill is the most important reason for learning a language.

- $\quad$ speaking is more important than knowing grammar.

- $\quad$ it provides permanence.

- $\quad$ when it is asked whether you know a foreign language, the first thing that you hear is "Can you speak?"

- $\quad$ a baby also learn to speak first, thus for learning a language it is the same.

Listening-comprehension is important because;

- $\quad$ listening and understanding is important because all the words need to be familiar for the learner.

- $\quad$ it takes you forward but the others save the moment.

- $\quad$ it is a condition for communication.

- $\quad$ it makes a positive contribution to our career.

- $\quad$ we cannot do well without understanding although we can talk, write and read something.

- $\quad$ writing and speaking cannot take place without understanding.

Writing is important because;

- $\quad$ it is the key and indicator of your other 3 skills.

- We can understand, read and talk very well in the future, but when we make mistakes in writing they may not provide feedback to us.

- $\quad$ as I write, I learn more words. As my vocabulary knowledge improves, my other writings become more effective, and so I develop myself.

Reading is important because;

- $\quad$ even a person who cannot have the slightest knowledge about the language may feel that he has learned something. In addition, as these skills are input skills grammar, vocabulary, and structures that will be used in speaking and writing skills can be obtained by reading

- we can improve our skills by understanding what is read. By understanding what we read, we can translate words.

12) Are there any unnecessary skills among them?

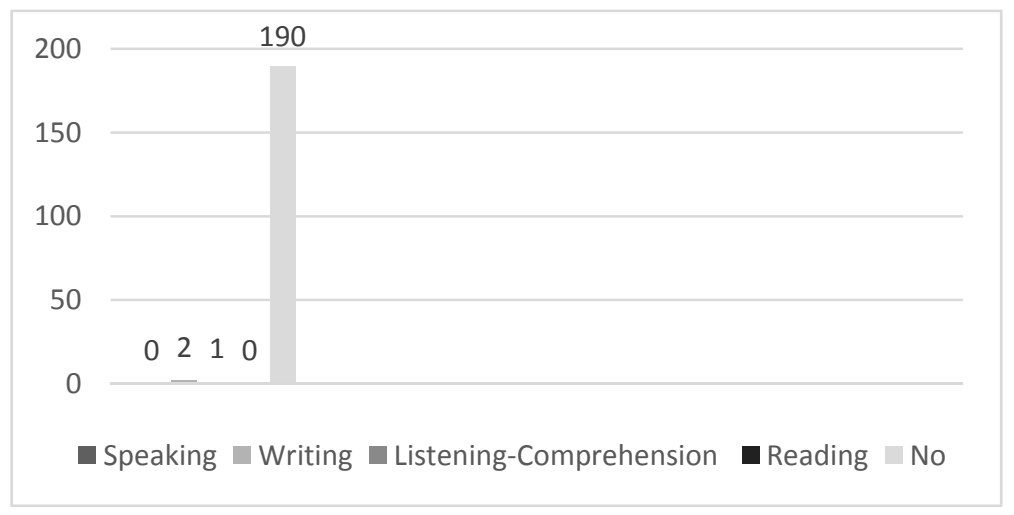

Figure 9. Unnecessary skill

This question can be seen as a summary to find out how they look at the four basic language skills in general, how important they are and whether they are aware of the indispensable elements in foreign language teaching. As a result, 190 students are of the opinion that there is no unnecessary skill by adding that each of which is important 
equally.

13) For which skill do you feel yourself best?

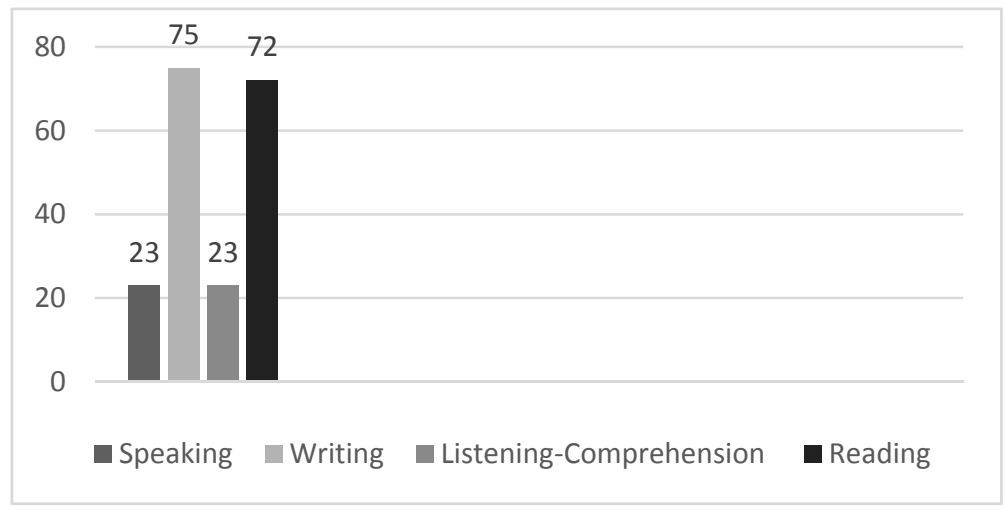

Figure 10. The best skill

$75 \%$ of the students have stated that they are good at writing skills while the other $72 \%$ have said that they are good at reading skills. The number of students who have indicated that they are good at speaking and listening comprehension skills is equal. This again redefines the relationship between these two skills.

14) For which skill do you feel yourself noncommittal?

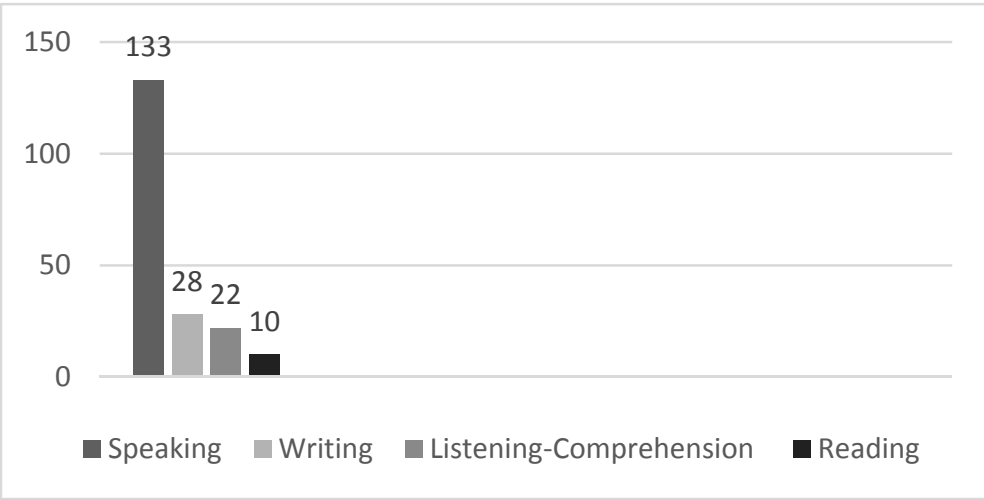

Figure 11. The skill seen as noncommittal

The students approach to speaking skills noncommittal and the reason for this is that it is the least used skill, and they are also avoiding talking because of the fear of making mistakes. I feel a lot of hesitation. I fear that people will laugh at me.

15) Which skill takes you away from foreign language learning? Why? 


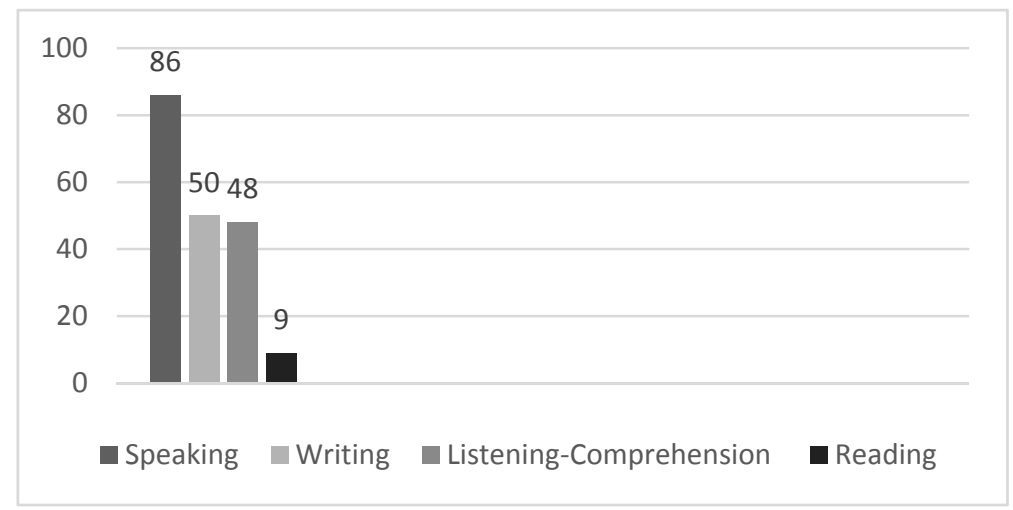

Figure 12. The skill taking one away from learning

The answers for this question are stated one by one to clarify the problem.

- I cannot talk, so I'm reluctant.

- $\quad$ Writings written to improve writing skills are often boring.

- I am reluctant as I cannot speak and express myself and I am afraid to make mistakes. Speaking lessons are inadequate.

- I think I cannot learn the language when I do not understand the words, and this demotivates me.

- $\quad$ Even talking by using the mother tongue means taking an active role. In other words, speaking is the skill that the person can avoid most, thus it may cause the person to be distracted.

- I I take care of the details while writing, so it takes a long time which makes me feel bored in time.

- I have a lot of difficulty in listening, and when I do not understand I feel myself very disturbed.

- When I cannot figure out what I'm hearing, I cannot feel myself enthusiastic.

- I am ashamed of making mistakes in pronunciation during reading.

- I want to write very effectively, but I lose my eager when I see that I have not reached to that level yet.

- I I feel like I do not know anything when I cannot understand.

- When I cannot speak, I hesitate and I do not want to learn that language in the course of time.

16) How do you rank the four basic skills in teaching and learning?

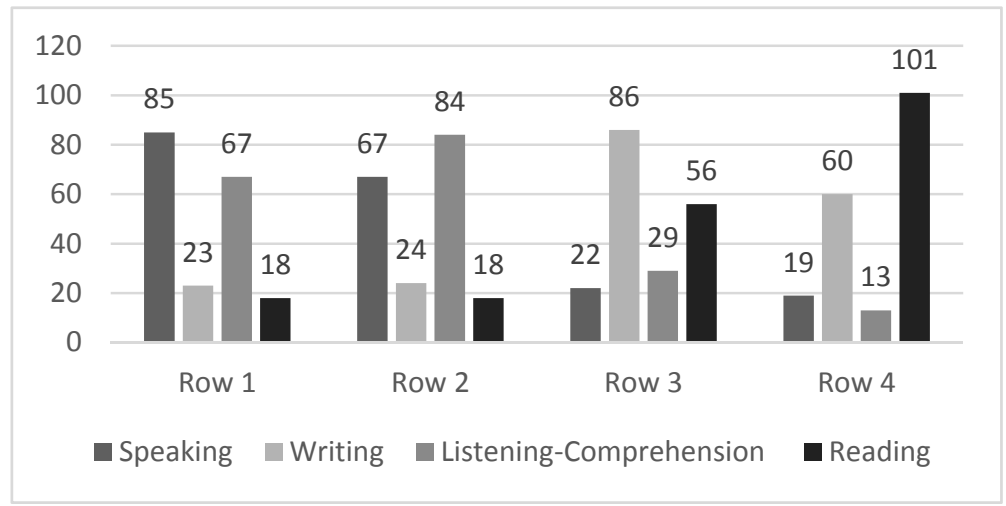

Figure 13. Rank of importance of the skills by students

Many questions were asked similar to this question, actually a summary has been intended for these questions by create awareness for the students. In this case, the most important skill is speaking when all the results are looked 
at. The second most important skill is listen-comprehension. In fact, most of the students have pointed out that they have chosen speaking as the most important skill and listening-comprehension skills are also very important as they want to develop themselves in this field by stating that these skills are among their primary goals. Writing comes in the third place, and reading skill is seen as the fourth important skill.

17) Which skill can you develop alone without having professional training?

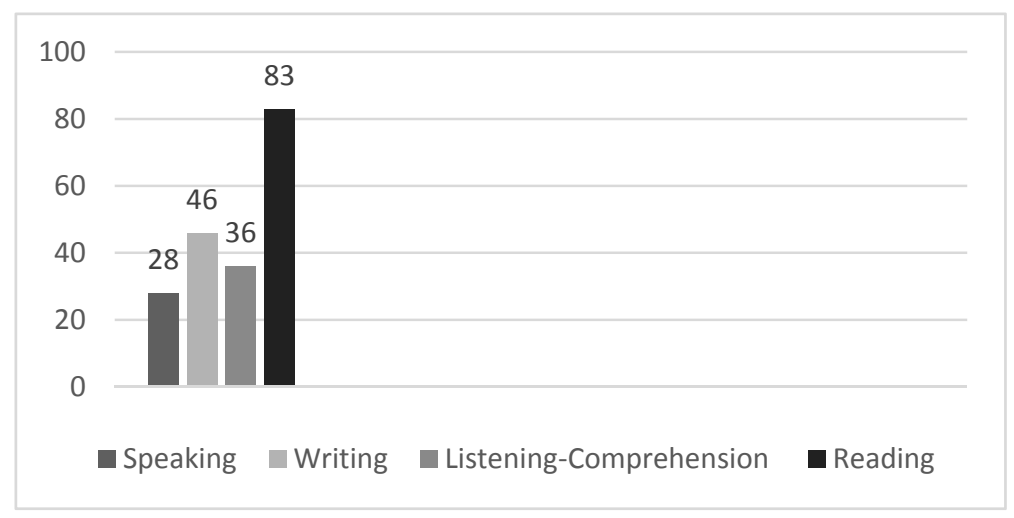

Figure 14. Skill that can be improved without having training

The students are aware of the fact that they can improve their writing and reading skills on their own, however they are aware that at least one person is required to perform these skills and so they accept that they need to have a professional education in order to be able to speak and understand what they hear.

\section{Conclusion, Discussion and Suggestions}

In this research, it is aimed to reveal the opinions of the students about the four basic language skills while learning a foreign language. A general evaluation of the opinions of the university students regarding the four basic language skills in the above 17 items have been made and the following conclusions have been reached:

1) $57.52 \%$ of the learners have the opinion that the most difficult skill to be learned is speaking, thus they think that it is necessary to have more speaking lessons for German teaching. Indeed, students do not have the opportunity to speak German effectively out of the course.

2) A large proportion of students (51.81\%) have stated that reading skills are easy to be learned and the reason behind this lies the fact that reading is seen in all other courses.

3) The fact that $35.23 \%$ of the students enjoyed speaking skills and $31.09 \%$ of them enjoyed reading skills showed that some students enjoyed speaking although they find it difficult and the others are enjoying the reading skills because they do not have anxiety while doing it.

4) $68.91 \%$ of the students have found the speaking skills as the most effective one. The students have the opinion that foreign language will be more lasting and effective by speaking.

5) $80 \%$ of the students have stated that there is no need to add a different skill to the four basic language skills and this have proven that it is enough to concentrate on these four basic skills. Only $15 \%$ of the students have stated that a skill that can reflect the foreign language culture should be added. Moreover, vocabulary and linguistic knowledge can be added as a skill. In this context, the effect of translation is undeniable and it can take its place as a skill in foreign language teaching.

6) Speaking skill is the primary target of students with $71.5 \%$. Students see themselves as inadequate as long as their speaking skills haven't developed, which in fact indicates that the instruction should focus on speaking more intensely. The motivation of the students is of great importance for effective learning.

7 )/8) While $56,48 \%$ of the students perceive themselves as inadequate in speaking skills, $10,88 \%$ of them perceive themselves as sufficient. Students see themselves $33.16 \%$ adequate in writing, \%15,54 inadequate; \%11,4 adequate in listening-comprehension, $\% 11,4$ inadequate and finally $\% 44,56$ adequate in reading and $\% 3,63$ inadequate. When these values have been examined, it is seen that there is a consistency among the answers of the previous questions given by the students. In this respect, it is necessary to emphasize the importance of the 
speaking skill in foreign language teaching and it has proven that the courses do not respond to the demands of the students.

9) Students with a focus on speaking skills, of course, want to improve the speaking skill most (76.68\%).

10)/11) While $77.2 \%$ of the students have regarded speaking skill as important, $52.85 \%$ have said that there is no insignificant skill, but according to data $29.53 \%$ of the students think that the reading ability is insignificant. Thus, it is clear that the speaking skill should be focused on much more if an education or training is wanted to be shaped according to the feelings and thoughts of the students.

12) $98.45 \%$ of students who are aware of the insignificant and unnecessary concepts have indicated that there is no unnecessary skill by adding that they are open to all skills.

13) Students have been asked to evaluate themselves in this question, and other questions have been answered honestly when the answers have been analyzed. The students have stated that they are better in writing with $38.86 \%$ than in reading with $37.31 \%$. This shows that more emphasis has been paid on writing and reading in lessons.

14) Another issue that is debated in foreign language education is that students have fear of talking due to their hesitation of making mistakes while speaking. This suggests that speaking skill is the most abstained skill with $68.91 \%$, which is one of the obstacle for an effective speaking oriented language teaching.

15) It has been revealed that $44.56 \%$ of the students say the speaking skills, $25.91 \%$ of them say the writing skills, $24.87 \%$ of them say the listening-comprehension skills, and $4.66 \%$ of them say the reading skills have taken them away from learning the foreign language lessons effectively. As they have inadequate skills in the sense of speaking, they see themselves as inadequate to learn the foreign language, and they also get bored about following foreign language lessons because they do not understand what is said or written during listening and reading. As the grammatical and lexical details are taken more into account during the writing process and thus the writing action takes more time, the students become frustrated and they get easily distracted. This requires foreign language lessons to be more intensively focused on the four basic skills.

16) In summary, $44.04 \%$ of the students have written speaking skills in the first rank, second most preferred skill listening comprehension (43.52\%), and the third most common is the writing skill (44.56\%) and reading skill is chosen with $52.33 \%$, which is the 4 th and the highest. As a result, a ranking of speaking, listening comprehension, writing and reading has been determined by the students. Thus, 'speaking skills' under the title of writing and speaking should be given much attention and emphasis.

17) Students think that they can develop reading and writing skills on their own; thus there should be done more work on speaking and comprehension in lessons.

When summarized from the results of the research, the skills that the students most want to develop, pay attention to and feel lacking are speaking skills. Students will be more successful and willing in the foreign language lessons when they hear and understand the target language correctly and can speak it effectively. This study reveals how important these skills are for verbal communication and how much it is necessary to acquire them with different approaches and methods in foreign language lessons.

Of course, all the skills are complementary and none are indispensable. However, the lessons should be formed according to the conditions and demands. If the participants in the research are thought that they are the future teacher candidates; they can solve the writing and reading skills in their own lessons by taking advantage of different sources when necessary, but they will not be able to practice the target language effectively in their own lessons as teachers as long as they do not develop speaking skills. Thus, foreign language lessons will be predominantly prepared including writing, reading, and linguistic knowledge.

\section{References}

Aktaş, T. (2004). Yabancı Dil Öğretiminde İletişimsel Yeti. Selçuk Üniversitesi Sosyal Bilimler Enstitüsü Dergisi, $12,45-57$.

Aslan, C. (2010). Türkçe Eğitimi Programlarında Lisansüstü Öğrenim Gören Öğrencilerin Akademik Özyeterliklerine İlişkin Görüşleri. Mehmet Akif Ersoy Üniversitesi Eğitim Fakültesi Dergisi, 10(19), 87-115.

Bağçeci, B., \& Yaşar, M. (2007). Ortaöğretim Kurumlarında İngilizce Öğretimine İlişkin Öğrenci Görüşleri, Gaziantep Üniversitesi Sosyal Bilimler Dergisi, 6(1), 9-16.

Balcı, A. (2007). Sosyal Bilimlerde Araştırma: Yöntem, Teknik Ve İlkeler. Ankara: Pegem A Yayıncılık 
Balc1, T. (2015). Die Erweiterung des Wortschatzes: Eine Analyse am Beispiel Türkisch-Deutsch. Festschrift für Prof. Dr. Yılmaz Özbek zum 67. Geburtstag, Sarı, A., Ed., Çizgi, Konya, 73-82.

Balc1, Y. (2000). Kreatives Schreiben als Hilfe beim Erwerb der Leseund Schreibfertigkeiten. In: 7. Türkischer Germanistik-Kongress, Tagungsbeiträge, H.Ü.Philologische Fak.Ankara, 523-528.

Barın, M. (1997). Dinleme-Konuşma Becerilerinin Önemi, Dil Öğretimine Katklları Ve Atatürk Üniversitesi İngiliz Dili Bölümlerinde Uygulanışı (Yayımlanmamış Doktora Tezi). Atatürk Üniversitesi/Sosyal Bilimler Enstitüsü, Ġngiliz Dili Ve Edebiyatı Anabilim Dalı, Erzurum.

Barın, M. (2002). Yabancı Dil Öğretiminde Dinleme Becerisin Önemi. Atatürk Üniversitesi Journal of Social Sciences, 2(28-29), 17-22.

Becker-Mrotzek, M. (2008). Gesprächskompetenz vermitteln und ermitteln: Gute Aufgaben im Bereich Sprechen und Zuhören. In A. Bremerich-Vos, G. Granzer, \& O. Köller (Hrsg.), Lernstandsbestimmung im Fach Deutsch. Gute Aufgaben für den Unterricht (pp. 186-195), Weinheim: Beltz.

Çakır, İ. (2010). Yazma Becerisinin Kazanılması Yabancı Dil Öğretiminde Neden Zordur? Sosyal Bilimler Enstitüsü Dergisi, 28, 165-176.

Deneme, S., \& Demirel, Ö. (2012). Yabancı Dilde Yazma Becerisinin Gelişiminde Özetleme Tekniğinin Öğretimi Ve Başarıya Etkisi. Dil Dergisi, 157, 49-64.

Drese, K. (2008). Einschätzung der Sprechleistung von Lernern im Englischunterricht der Grundschule (Dissertation, Universität Gießen). Retrieved from http://geb.uni-giessen.de/geb/volltexte/2008/6338/pdf/ DreseKarin-2008-06-26.pdf

Genç, A. (1997). Alman Dili Eğitimi Öğrencilerinde Yazma Alışkanlı̆̆ı, Hacettepe Üniversitesi Ĕgitim Fakültesi Dergisi, 13, 127-134.

Günay, V. D. (2007). Metin Bilgisi. İstanbul: Multilingual.

Işık, A. (2008). Yabancı Dil Eğitimimizdeki Yanlışlar Nereden Kaynaklanıyor?, Journal Of Language And Linguistic Studies, 4(2), 15-26.

Kavanagh, M. H., \& Drenan, L. (2008). What skills and attributes Does year accounting graduate need? Evidence from student perceptions and use expectations. Accounting and Finance, 48, 279-300. https://doi.org/10.1111/j.1467-629X.2007.00245.x

Krippendorff, K. (2004). Content Analysis. London: Sage Publications.

Neuendorf, K. A. (2002). The Content Analysis Guidebook. London: Sage Publications

Punch, K. F. (2005). Sosyal Araştırmalara Giriş: Nicel Ve Nitel Yaklaşımlar. Ankara: Siyasal Kitabevi.

Şahin, A. (2010). Avrupa Dil Gelişim Dosyası Bağlamında Yabancı Dil Olarak Türkçe Öğretiminde Okuma Becerisini Geliştirmeye Yönelik Malzeme Oluşturma (Unpublished master's thesis). Dokuz Eylül Üniversitesi, Eğitim Bilimleri Enstitüsü, İzmir.

Tavşancıl, E., \& Aslan, E. (2001). İçerik Analizi Ve Uygulama Örnekleri. İstanbul: Epsilon Yayıncılık.

Yıldırım, A., \& Şimşek, H. (2006). Sosyal Bilimlerde Nitel Araştırma Yöntemleri. Ankara: Seçkin Yayınevi.

Yıldız, Ü. (2015). Yabancı Dil olarak Türkçe Öğretiminde Dil Becerilerine Yönelik Öğrenci ve Öğretmen Görüşleri. International Journal of Language's Education and Teachning, 3(1), 429-443.

\section{Copyrights}

Copyright for this article is retained by the author(s), with first publication rights granted to the journal.

This is an open-access article distributed under the terms and conditions of the Creative Commons Attribution license (http://creativecommons.org/licenses/by/4.0/). 